\title{
Green Open Space Functions in Kauman Area, Semarang City, Indonesia
}

\author{
Intan Muning Harjanti, Pratamaningtyas Anggraini \\ Vocational School, Universitas Diponegoro, Indonesia \\ Corresponding e-mail: intanmuning@live.undip.ac.id
}

Article info:

Received: 30-01-2020, Revised: 07-05-2020, Accepted: 14-09-2020

\begin{abstract}
Green open space has a variety of functions, which will help realize environmental balance and harmony. Kauman Area is one area in the city of Semarang whose inhabitants are dominated by people of Arab descent, which not only functions as a settlement, but also develops into trading activities spread along the Kauman Street corridor. The purpose of this study is to identify the functions of Green Open Space in Kauman Area, Semarang City, Indonesia, and approach used in this research is descriptive qualitative, which conducted by inductively. Based on the results, the functions of green open space in Kauman Area, both private and public green open space, it was found that private green open space located in residential areas, office areas, education area, and in the worship area. Whereas existing public green open space consists of urban parks in the form of aloon - aloon and green lane in the form of road borders. Private green open space in residential areas has ecological, economic and aesthetic functions; Private green open space in office areas is dominated by ecological functions; while green space in the areas of education, worship, trade and services, is dominated by ecological and aesthetic functions. Whereas public Green Open Space in the form of urban park has an economic function; Green Open Space green lane in the form of road borders, island road, and road median has ecological and aesthetic function; and Green Open Space with specific function in the form of river borders has the ecological and aesthetic function.
\end{abstract}

Keywords: identification, green open spaces, green open spaces functions

\section{Introduction}

Open Space is a planned space because of the need for meeting places and joint activities in the open air. With a joint meeting and relations between people, there will likely be various activities in the open public space (Budihardjo \& Sujarto, 2009). According to (Hakim, 2003), open space is divided into green open spaces and non-green open spaces. Green open space (GOS) is one part of the spatial plan that is located as a determinant of the balance of the environment and built environment because Green Open Space (GOS) is the lungs of the city. So, it must always be preserved and developed because green space is an important component of urban areas (Schetke, Haase, \& Breuste, 2010). Besides, green open space also influences the physical and mental health well (Dadvand et al., 2015) and it is an environmental resource that can have a positive impact on people's quality of life and property value (Haran et al., 2014). Green open space has a variety of functions, which of course will help realize environmental balance and harmony. The function will later be able to maximize the use of existing RTH. Because though Green space planning has been regulated in standards and guidelines, but people's understanding of green space is slightly different (Ives et al., 2017). Whereas, active participation from a well-organized society will be able to express neo-cities concepts (Seeland, Dübendorfer, \& Hansmann, 2009).

The city of Semarang is the capital of Central Java Province, with an area of $373.70 \mathrm{~km}^{2}$ and an area of sea area of approximately 18000 ha. The Semarang urban community is relatively diverse from an ethnic standpoint, because the city of Semarang has become the center of 
administrative, industrial, economic, and other social facilities. So that many people from various ethnic groups live in Semarang, one of which is in the Kauman area. This Kauman area is located in Kelurahan Kauman, Kecamatan Semarang Tengah, Semarang City. Historically, the emergence of the Kauman area began with the arrival of Ki Ageng Pandan Arang, who at that time carried a mission to spread Islam. Then he built a mosque located west of the river Kali Semarang as a means of carrying out its mission, called the Kauman Mosque. More and more people followed his teachings, then his followers settled around the mosque. So far it is known by the name of the Kauman area, where the people are dominated by people of Arab descent. But over time, this area is also inhabited by indigenous people who blend in with the indigenous population. This Kauman area not only functions as a settlement, but also develops into trading activities spread along the Kauman Street corridor. For the Kauman community, social and religious life cannot be separated from trading activities. Their lives are driven by economic, social, cultural and religious activities. The density of activities in this area, certainly there is a need for discussion about the space that serves as a counterweight to these various activities, which one of them is the Green Open Space. Because the development of a dense city in an urban green space will cause city problems (Haaland \& van den Bosch, 2015).

The purpose of this study is to identify the functions of Green Open Space in Kauman Area, Semarang City, Indonesia. The results of this study will be useful in understanding the availability of green open space in Kauman Area and its functions. It also can be used as input to conduct further research related to the availability and fulfillment of green space for local residents.

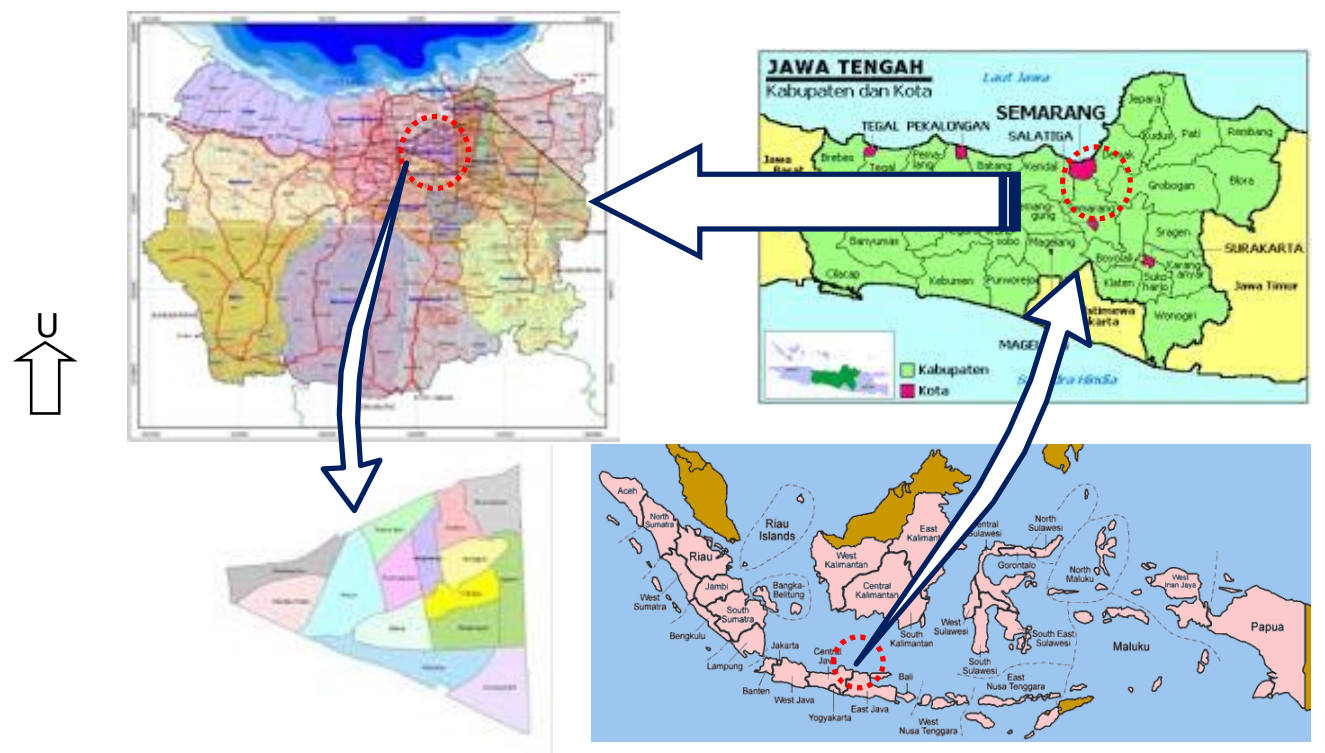

Figure 1. 1. Location of Study Area, Kauman Area, Semarang City (Analysis, 2019)

\section{Methods}

The approach used in this research is descriptive qualitative, which conducted by inductively. This is because the objectives to be achieved in this study will be known when this research is completed. While the qualitative descriptive approach is used because in analyzing the functions of green open space in Kauman Area by identifying directly the various types of green space in the study area. So that, eventually it will get information about what green open space functions have in Kelurahan Kauman. 
Data collection methods used are primary and secondary. Primary data collection is performed with direct observation of objects in the study area location, namely green open space in Kelurahan Kauman. While the secondary data collection is performed with examining data obtained from agencies, as well as data obtained in addition to primary data collection, in this case in the form of information related to green space in Kelurahan Kauman and observing objects obtained from Googlemaps.

\section{Discussion}

Based on the nature of ownership, green open space is divided into private and public green open space (Departemen Pekerjaan Umum, 2008). Private green open space ownership and management is held directly by the owner, as well as in its use only certain people, that is those who are entitled and have an interest in the area of the green open space. Whereas the ownership of public green space is more general in nature, that is, the community is free to access and use it, as well as its management is managed directly by the local government and its existence is indeed functioned to serve and meet the needs of the community. Based on Peraturan Menteri Pekerjaan Umum Number 5 of 2008 concerning Guidelines for Provision and Utilization of Green Open Spaces in Urban Areas, types of public green open spaces consist of: green open space of city parks; city Forest; Green Open Space green line road, consisting of island road and median road; as well as a specific function of the Green Open Space, which consists of the Green Open Space of the railroad and river borders.

Still according to (Departemen Pekerjaan Umum, 2008), Green Open Space has two functions: intrinsic and extrinsic. Intrinsic function on ecological functions: as the lungs of the city; micro climate regulators, as a shade; oxygen producer; rainwater absorbent; provider of wildlife habitat; pollutants absorbent; and windbreak. While extrinsic functions, on social and cultural functions: describing local cultural expressions; citizen communication media; recreation areas; object of education, research, and training in studying nature. And on economic functions: source of products that can be sold, such as flowers, fruits, leaves, vegetables; can be part of agricultural, plantation, forestry and other businesses. On aesthetic functions: increasing of comfort and beauty of city environmental, both from the micro and macro scale; stimulate the creativity and productivity of citizens; forming architectural beauty factors; create a harmonious atmosphere and balance between the built and unconscious areas.

\subsection{Private Green Open Space}

Private Green Open Space in Kauman Ares is Green Open Space in residential areas, offices, education, worship, as well as in trade and service areas. Existing private Green Open Space is the ownership of citizens and private, where the management and use is regulated in accordance with ownership.

\subsubsection{Green Open Space in Settlement Area}

Green Open Space settlements in the Kauman area are dominated by ecological functions, that is as a shade, economic and aesthetic. This can be seen in Figure. 3.1, that residents plant vegetation with shade tree species as an ecological function, then fruit tree species as economic functions, and flower vegetation types as aesthetic functions. The shade tree species functioned as an ecological function because it can create a cool microclimate in the residents' residential areas, the fruit tree species functioned as an economic function 
because later on the fruit of the tree can be directly consumed by residents or traded, while flower plants as an aesthetic function because can provide beauty in the residential area.
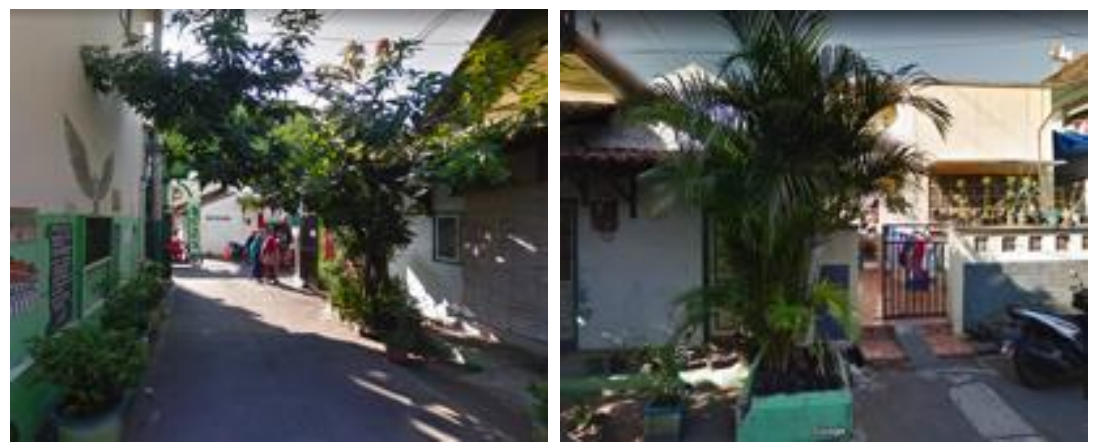

Figure 3.1. Green Open Space in Settlement Area (Googlemaps, 2019)

\subsubsection{Green Open Space in Office Area}

Private Green Open Space in office area located in Kauman Area, dominated by aesthetic functions. This can be seen in Figure 3.2, the type of vegetation planted in the area is of the type of flowering plants, which are planted in pots and placed in front of buildings and shrub types planted in the front lawn. So the purpose of the plant is to give an element of beauty in the office area, even though its presence looks very minimal due to limited space.

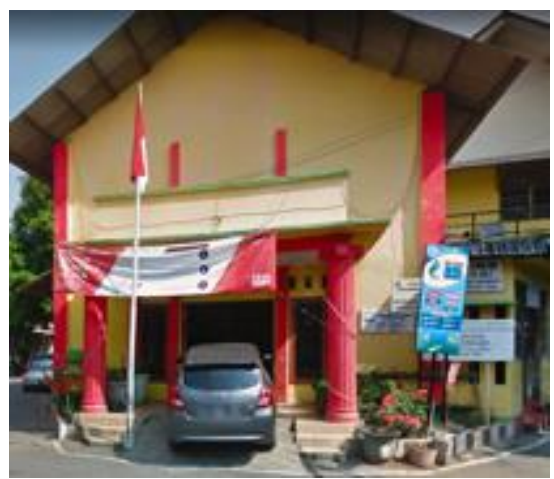

Figure 3.2. Green Open Spaces in Office Area (Googlemaps, 2019)

\subsubsection{Green Open Space in Education Area}

Private Green Open Space in the Education area in Kauman area is dominated by ecological and aesthetic functions. Ecological function because vegetation planted in the education area are herbaceous and shade trees, which aim to reduce noise, pollution and as a shade. Meanwhile, it functions aesthetically because besides being planted with shrubs and shade trees, it is also planted with flower plants, which aim to create beauty.
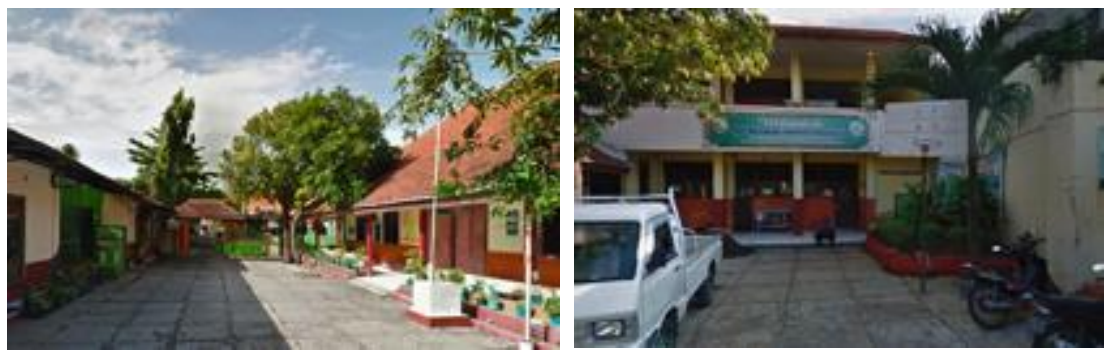

Figure 3.3. Green Open Spaces in Education Area (Googlemaps, 2019) 


\subsubsection{Green Open Space in Worship Area}

Worship facilities in the Kauman Area, there are two small mosques and one large mosque, the Kauman Mosque. The character of green open space contained in these facilities is different, where the mosque facility has two functions at once, which is ecological as well as aesthetic functions. Whereas in the small mosque facilities, the existence of green open space is very limited and almost not available, which is only fulfilled by the vegetation of the residents who live nearby. Can be seen in Figure. 3.4, the green open space at the mosque facility is planted with palm trees, which in addition to functioning as a shade can also function as a beauty enhancer, because of the beautiful shape of the tree and planted in a row. Whereas there are no plants available on the small mosque, there are only plants belonging to residents with a type of herbaceous on the other side.
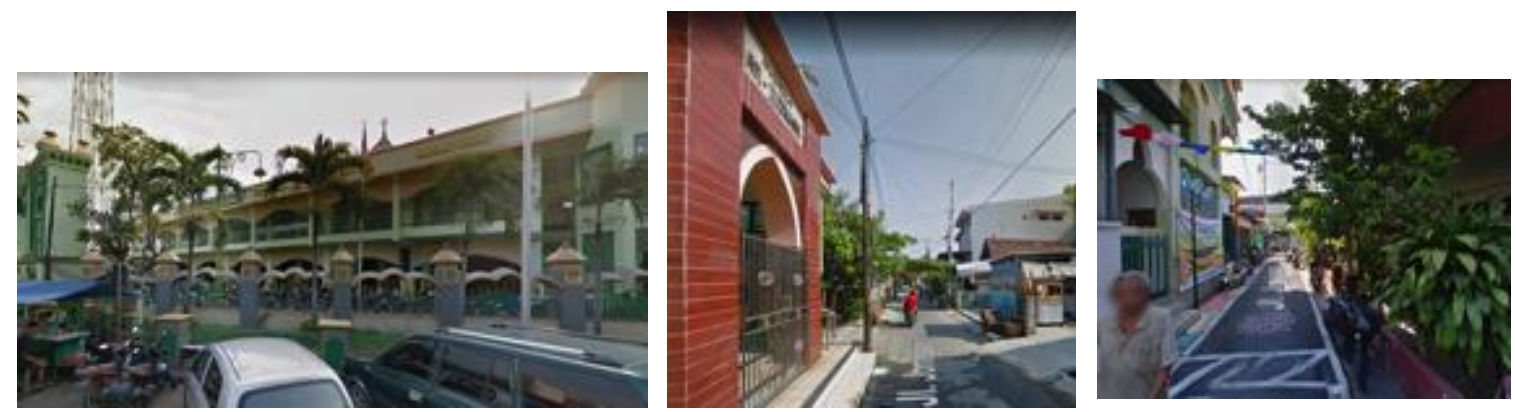

Figure 3.4. Green Open Space in Worship Area (Googlemaps, 2019)

\subsubsection{Green Open Spaces in Trade and Services Area}

Private green open space in the area of trade and services in the Kauman Area, is dominated by ecological and aesthetic functions. This can be seen in Figure. 3.5., that plants which are planted in the trade and service area are of shade trees that function as shading for the perpetrators of activities and to reduce pollution because they also function as road borders. While the aesthetic function is indicated by the planting of flowers and palm trees on the hotel yard that aims to add beauty.
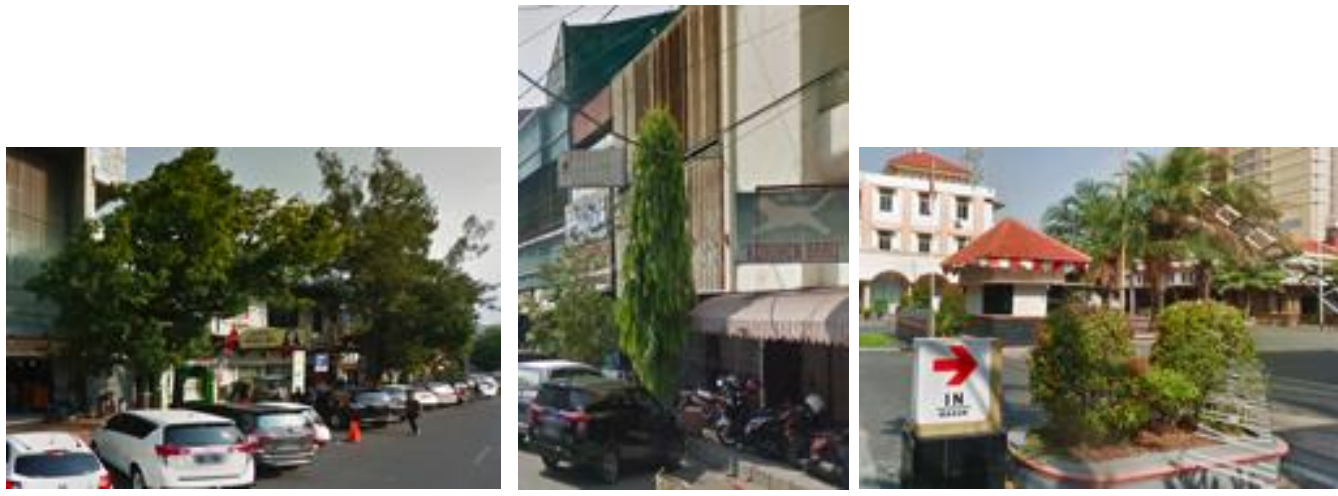

Figure 3.5. Green Open Spaces in Trade and Services Area (Googlemaps, 2019) 


\subsection{Public Green Open Space}

Public Green Open Space located in Kauman Area consists of urban park and green lane, yang meliputi road border and road island.

\subsubsection{Urban Park}

Urban park located in the Kauman Area is Aloon - Aloon Semarang with the size $120 \mathrm{~m} \times 60$ $\mathrm{m}$, which can be used by the community for activities. However, currently this square is under construction, so that it can later be utilized by the community more optimally, such as for sports and recreation areas. In addition, Aloon - Aloon Semarang will also be equipped with basement parking for visitors, so that visitors can park the vehicle neatly and safely and not interfere with other activities in the vicinity. Previously, the square was in the form of a field which, over time, turned into an area for trading. This is because its location is directly adjacent to the Johar Market which is a trading area. So that causes the square is not functioning properly. Therefore, with the rebuilding of the Johar Market that was previously burned, the Semarang City Government also rebuilt the Aloon - aloon Semarang, in order to create an active public Green Open Space park that is suitable for its function for the community. So that for now the Aloon - aloon Semarang has only an economic function. Because of its location which borders the Johar trade and service area, so many sellers are used for trading in this area.
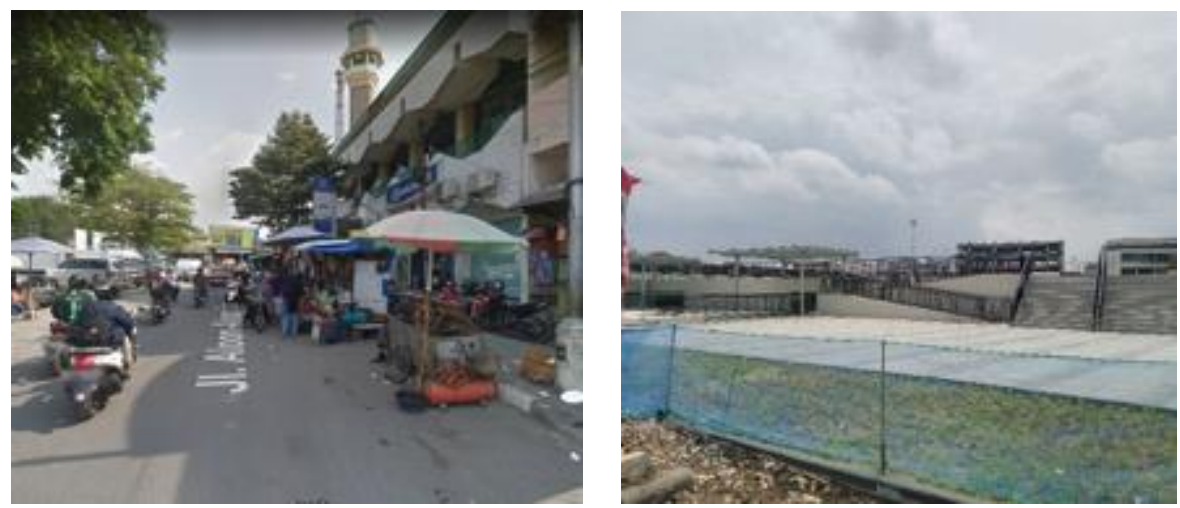

Figure 3.6. (a) Aloon - Aloon Semarang Area Now (Googlemaps, 2019); (b) Aloon - Aloon Semarang on Progress (Observation, 2019)

\subsubsection{Green Open Space Green Lane}

Green Open Space green lane located in Kelurahan Kauman is in the form of road borders, river borders and road medians.

\section{a. Road Borders}

Road Borders in the Kauman Area is located on collector roads and local roads. On the collector road there are along Jalan Pemuda, especially in the access road to the Old Town area. Whereas on local roads there are along roads in the trade and service area. Green lane with the type of road borders in the Kauman Area has ecological and aesthetic functions. This can be seen in Figure 3.7. that the type of vegetation planted is dominated by shade trees, which are planted in a row, so that in addition to helping reduce pollution and noise, it can also create beauty for road users. 

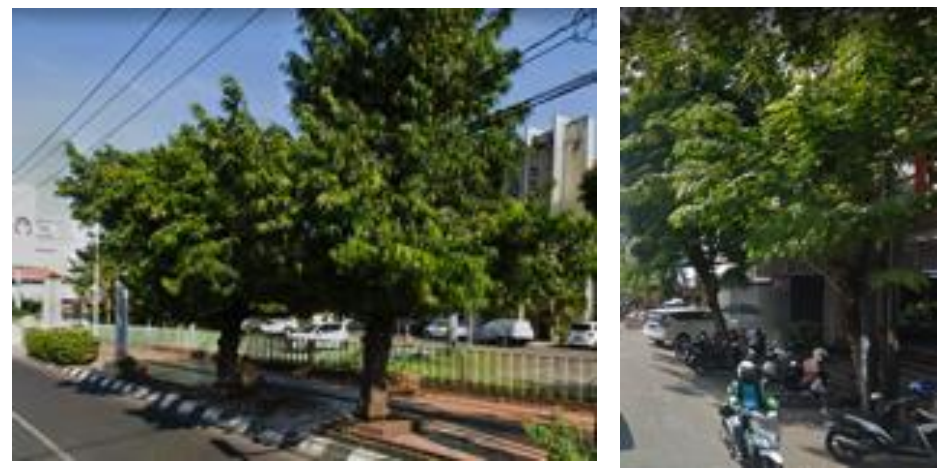

Figure 3.7. Road Borders in Kelurahan Area (Googlemaps, 2019)

b. Road Island

Road island in the Kauman Area is located at one corners of the Jalan Pemuda intersection. This road island functions ecologically and aesthetically. This can be seen from the type of vegetation that is planted, in the form of ornamental herbaceous plants that are planted in such a way as to beautify the area and shade trees that can help reduce pollution.

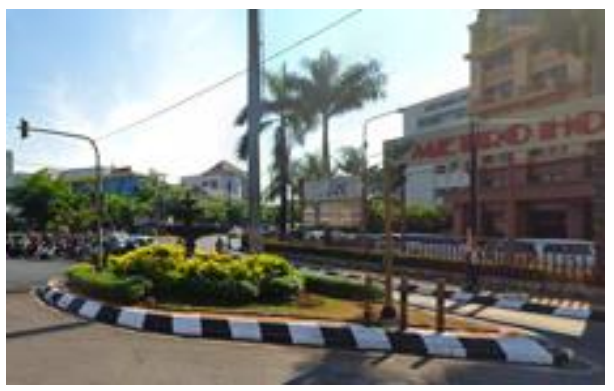

Figure 3.8. Island Road at Pemuda Street Crossroads (Googlemaps, 2019)

\subsection{Green Open Space Functions in Kauman Area}

Green open spaces in the Kauman Area are distinguished by their location and shape, namely private green open spaces in the form of courtyards around buildings located in the settlement area, office area, education area, worship area and trade and services area. Whereas public green open space is urban park with the type of aloon - aloon and green lane with road borders. Based on the analysis that has been done, it can be seen that the function of green open space in the Kauman Area is generally dominated by ecological and aesthetic functions. This is identified based on the type of vegetation in each of the allotment of green open space, shape, and location, where the type of vegetation is dominated by shade tree species that function to reduce air pollution, noise and create a cool microclimate. While the aesthetic function can be seen from the type of vegetation in the form of ornamental shrubs and flower plants. The economic function is only found in the settlement area and the square. In the settlement area can be identified from the type of vegetation that is planted in the form of plants that can provide economic value, such as fruit trees. While the square is identified based on the allocation of space, which is more functioned for trading activities / economic activities. 
Table 3.1. Green Open Space Functions in Kelurahan Kauman (Analysis, 2019)

\begin{tabular}{|c|c|c|c|}
\hline $\begin{array}{c}\text { Characters } \\
\text { of Green } \\
\text { Open Space }\end{array}$ & $\begin{array}{l}\text { Form of Green } \\
\text { Open Space }\end{array}$ & $\begin{array}{l}\text { Types of Green Open } \\
\text { Spaces }\end{array}$ & Functions \\
\hline \multirow[t]{10}{*}{ Private } & Building yards & Settlement Area & Ecologic \\
\hline & & & Economic \\
\hline & & & Aesthetic \\
\hline & & Office Area & Aesthetic \\
\hline & & Education Area & Ecologic \\
\hline & & & Aesthetic \\
\hline & & Worship Area & Ecologic \\
\hline & & & Aesthetic \\
\hline & & Trade and services area & Ecologic \\
\hline & & & Aesthetic \\
\hline \multirow[t]{3}{*}{ Public } & Urban park & Aloon - aloon & Economic \\
\hline & Green lane & Road borders & Ecologic \\
\hline & & & Aesthetic \\
\hline
\end{tabular}

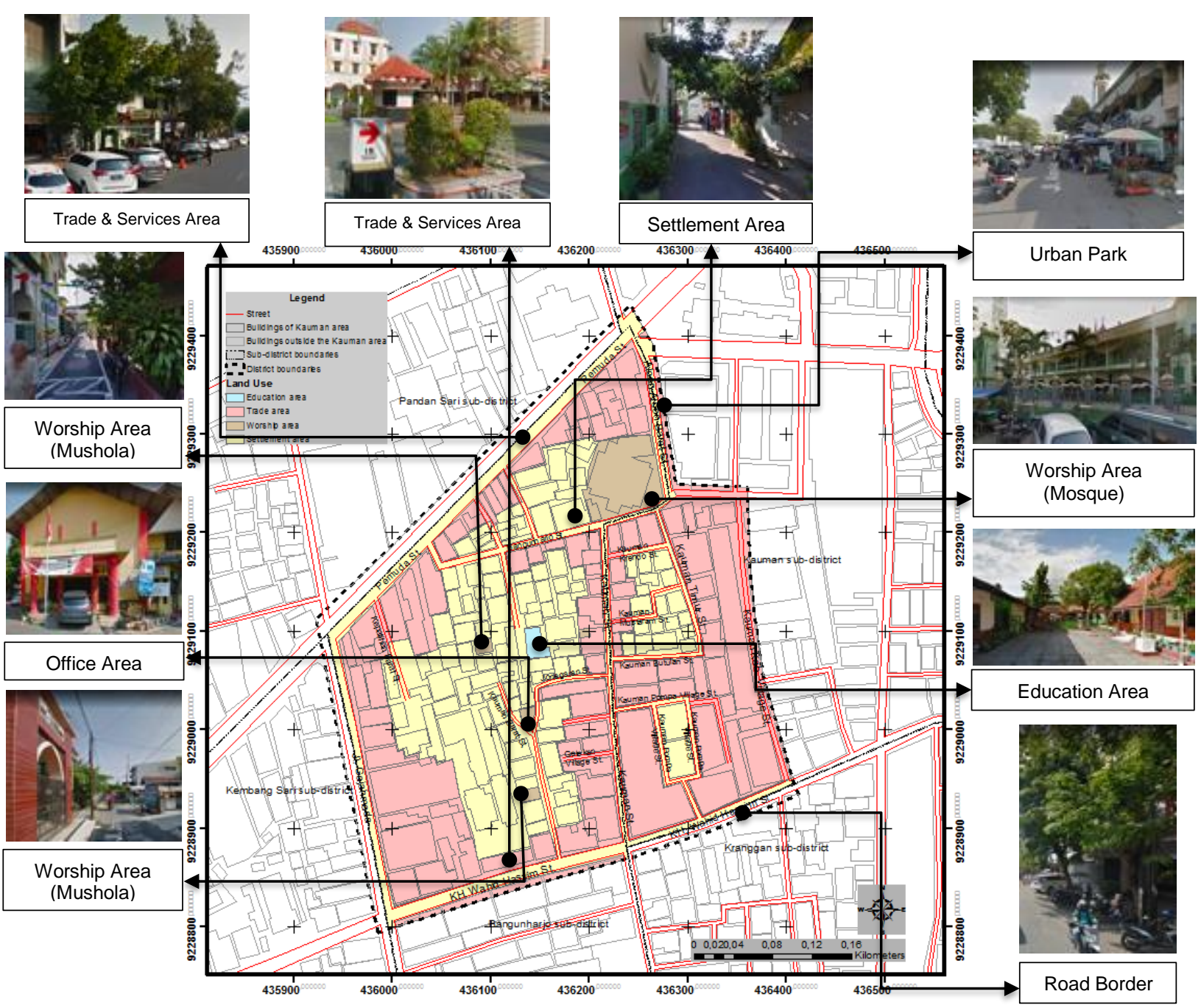

Figure 3.9. Mapping of Green Open Space Functions in The Kauman Area (Analysis, 2019) 


\section{Conclusion}

The Green Open Space in Kauman Area consists of private and public Green Open Space. The type of private Green Open Space is Green Open Space in residential areas, office areas, education area, worship area, and in trade and service areas. Whereas public Green Open Space in the form of urban park and green lane (road border, island road). Each type of green space has a variety of functions. Based on the results of the analysis it was found that private Green Open Space in residential areas has ecological, economic and aesthetic functions; in office areas is dominated by aesthetic functions; in the education area is dominated by ecological and aesthetic functions; in the worship area functions ecologically as well as aesthetically; and private Green Open Space in the area of trade and services is dominated by ecological and aesthetic functions. Whereas public Green Open Space in the form of urban park has an economic function; Green Open Space green lane in the form of road borders and island road has the same function, namely ecological and aesthetic function. So, based on the analysis that has been done, it can be seen that the function of green open space in the Kauman Region is generally dominated by ecological and aesthetic functions. Whereas the economic function is only found in the settlement area and Aloon Aloon.

\section{Acknowledments}

The authors thanks to Vocational School, Diponegoro University, as the research funder. And the manager of JADU who has helped publish this article

\section{References}

Budihardjo, E., \& Sujarto, D. (2009). Kota Berkenlanjutan. Bandung: PT. Alumni.

Dadvand, P., Nieuwenhuijsen, M. J., Esnaola, M., Forns, J., Basagaña, X., Alvarez-Pedrerol, M., ... Sunyer, J. (2015). Green spaces and cognitive development in primary schoolchildren. Proceedings of the National Academy of Sciences, 112(26), 7937 LP 7942. Retrieved from http://www.pnas.org/content/112/26/7937.abstract

Haaland, C., \& van den Bosch, C. K. (2015). Challenges and strategies for urban greenspace planning in cities undergoing densification: A review. Urban Forestry \& Urban Greening, 14(4), 760-771. https://doi.org/10.1016/J.UFUG.2015.07.009

Hakim, R. D. (2003). Komponen Perancangan Lansekap. Jakarta: Bumi Aksara.

Haran, M., Davis, P. T., McCluskey, W., McCord, M., McCord, J., \& Mcllhatton, D. (2014). Effect of public green space on residential property values in Belfast metropolitan area. Journal of Financial Management of Property and Construction, 19(2), 117-137. https://doi.org/10.1108/JFMPC-04-2013-0008

Ives, C. D., Oke, C., Hehir, A., Gordon, A., Wang, Y., \& Bekessy, S. A. (2017). Capturing residents' values for urban green space: Mapping, analysis and guidance for practice. Landscape and Urban Planning, 161, 32-43. https://doi.org/10.1016/j.landurbplan.2016.12.010

Menteri Pekerjaan Umum. 2008. Peraturan Menteri Pekerjaan Umum No. 05/PRT/M/2008 Tentang Pedoman Penyediaan dan Pemanfaatan Ruang Terbuka Hijau di Kawasan Perkotaan. Jakarta: Menteri Pekerjaan Umum.

Schetke, S., Haase, D., \& Breuste, J. (2010). Green space functionality under conditions of uneven urban land use development. Journal of Land Use Science, 5(2), 143-158. https://doi.org/10.1080/1747423X.2010.481081

Seeland, K., Dübendorfer, S., \& Hansmann, R. (2009). Making friends in Zurich's urban forests and parks: The role of public green space for social inclusion of youths from different cultures. Forest Policy and Economics, 11(1), 10-17. https://doi.org/10.1016/J.FORPOL.2008.07.005 